\title{
Physiological, Morphological Changes and Storage Root Yield of Sweetpotato [Ipomoea batatas (L.) Lam.] under PEG-Induced Water Stress
}

\author{
Suravoot YOOYONGWECH ${ }^{1}$, Thapanee SAMPHUMPHUNG ${ }^{2}$, \\ Rujira TISARAM ${ }^{2}$, Cattarin THEERAWITAYA ${ }^{2}$, Suriyan CHA-UM ${ }^{2 *}$ \\ ${ }^{1}$ Division of Agricultural Science, Mabidol University, Kanchanaburi Campus, Kanchanaburi 71150, Thailand \\ ${ }^{2}$ National Center for Genetic Engineering and Biotechnology (BIOTEC), National Science and Technology Development Agency (NSTDA), \\ Pathum Thani 12120, Thailand; suriyanc@biotec.or.th ( ${ }^{*}$ corresponding author)
}

\begin{abstract}
Sweetpotato is an important tuberous root crop rich in nutrients such as vitamins and carbohydrates, and can grow well in arid regions with less water consuming crop. The aim of this research was to evaluate the storage root yields, physiological, biochemical and morphological traits in sweetpotato cv. 'Japanese Yellow' subjected to polyethylene glycol (PEG)-induced water deficit. At harvest ( 4 months after planting) the number of storage roots per plant and storage root fresh weight in sweetpotato treated with 5\% PEG $(-0.54 \mathrm{MPa})$ in nutrient solution of hydroponic culture declined by $20.0 \%$ and $47.4 \%$ compared to the control without PEG, respectively. Leaf area and leaf dry weight significantly decreased by $85.6 \%$ and $95.3 \%$, respectively when exposed to water deficit stress. Sucrose content (114.7 $\mathrm{mg} \mathrm{g}^{-1}$ dry weight; DW) in storage roots of sweetpotato grown under PEG-induced water deficit conditions was enriched by 2.2 fold of control $\left(52.5 \mathrm{mg} \mathrm{g}^{-1} \mathrm{DW}\right)$ and was greater than in storage roots derived from soil culture $\left(70.3 \mathrm{mg} \mathrm{g}^{-1} \mathrm{DW}\right)$. Total soluble sugar in the root and storage root tissues was enriched and may play a key role as osmotic adjustment (OA) in PEG-induced water stressed plants. Free proline and sucrose contents were also dominated in the leaf tissues to maintain the leaf osmotic potential in water stressed plants. In addition, chlorophyll degradation, chlorophyll fluorescence diminution and stomatal closure were found in plants grown under PEG-induced water deficit conditions, leading to reduction in net photosynthetic rate $\left(\mathrm{P}_{\mathrm{n}}\right)$ and subsequently lesser amounts of glucose and fructose contents in the leaf tissues. Sucrose and free proline in the roots of sweetpotato play a key role as major osmotic adjustment when subjected to PEG-induced water deficit condition. Basic knowledge gained from this research will further be investigated the drought defense mechanism in sweetpotato via osmoregulation system.
\end{abstract}

Keywords: net photosynthetic rate, osmotic adjustment, polyethylene glycol (PEG), sucrose, total soluble sugar.

\section{Introduction}

Sweetpotato is used as a major carbohydrate resource in the developing countries where it is the fifth most important food crop (Mukhopadhyay et al., 2011). Apart from carbohydrates, the storage roots are rich in proteins, $\beta$-carotene, anthocyanins, ascorbic acid, potassium and calcium (Truong et al., 2010; Mukhopadhyay et al., 2011; Mohanraj and Sivasankar, 2014; Motsa et al., 2015). The green leaves are rich in anthocyanins, polyphenolic acid and essential oils (Islam et al., 2002; Islam, 2006; Wang et al., 2010). Orange-flashed sweetpotato, when consumed daily, can prevent vitamin A deficiency (Burri, 2011; Fitzpatrick et al., 2012). Storage roots of sweetpotato are rich in starch, vitamins and minerals. In general, storage root yield ranging from 20 to 25 tons $\mathrm{ha}^{-1}$ is a minimal requirement to validate the crop as an elite variety in a field trial (Nedunchezhiyan et al., 2012). The productivity of sweetpotato in P.R. China and United States of America (USA) has been bench-marked as 21.0 and 22.5 tons ha ${ }^{-1}$, respectively (Mukhopadhyay et al., 2011). In contrast, the productivity of sweetpotato in African countries such as Uganda, Nigeria, Tanzania, Angola, Burundi, Mozambique, Madaguscar, Rwanda, Ethiopia, Kenya and Cameroon is very low $\left(<10\right.$ tons ha $\left.{ }^{-1}\right)$, and hence improvement in the yield traits of sweetpotato is of prime importance to plant breeders (Tekalign, 2007; Placide et al., 2013; Andrade et al., 2016).

In sweetpotato production, water shortage in arid zone i.e. Africa, is a critical problem, especially in rainfed areas $(<500$ $\mathrm{mm} \mathrm{yr}^{-1}$ precipitation), resulting in lower productivity (6.6 tons 
$\mathrm{ha}^{-1}$ in rainfed) when compared to other regions (12.5 tons ha $\mathrm{h}^{-1}$ in 30\% full irrigation) (Önder et al., 2015). Sweetpotato has been identified as a moderate drought tolerant crop and it is very sensitive to water deficit in storage root initiation stage (10-40 days after planting) (Mukhopadhyay et al., 2011; Villordon et al., 2012). Earlier studies indicate that the physiological responses including water potential, photosynthetic pigment contents, chlorophyll fluorescence, net photosynthetic rate, stomatal conductance, transpiration rate and water use efficiency of sweetpotato cvs. 'Beauregard' and 'Evangeline' grown under reduced soil moisture $\left(0.107 \mathrm{~m}^{3}\right.$ $\mathrm{H}_{2} \mathrm{O} \mathrm{m}{ }^{-3}$ soil) were significantly dropped. This lead to growth reduction in sweetpotato which was identified by low number of leaf, reduced leaf area and retarded vine length which resulted in delayed storage root formation and storage root yield reduction (Gajanayake et al., 2013, 2014). Screening drought tolerant trait in sweetpotato in the field trial of arid regions has been evaluated using storage root yield as major criteria (Laurie et al., 2013; Maquia et al., 2013; Kivuva et al., 2015; Andrade et al., 2016). The field trial evaluation is performed at least two crop cycles to collect the data following validated recommendation before release of the candidate varieties to the farmers. Fifty-nine genotypes of orange-fleshed sweetpotato have been screened for drought tolerant traits (shoot height, shoot fresh weight, shoot dry weight, root dry weight and leaf area) in plant tissue culture using PEG $_{6000^{-}}$ induced water deficit in the culture medium. Of these, 8 candidate genotypes, 194515.5, 194539.36, 441724, 441538, 189135.9, 41768, 192033.5 and 440429, were identified as drought tolerant (Agilis et al., 2015). In addition, sweetpotato cv. 'IWA1' has been identified as water deficit tolerant by shoot height, leaf fresh weight, root length and root dry weight using PEG 8000 -induced water deficit (Gopal and Iwama, 2007).

Recently, hydroponic culture system for storage root development of sweetpotato has been investigated with controlled environments i.e. plant spacing (Mortley et al., 1991), photoperiod (Mortley et al., 2009), light intensity (Mortley et al., 1996), substrate moisture content (Eguchi et al., 1995), ambient relative humidity (Mortley et al., 1994; Eguchi et al., 1998) and planting depth (Islam et al., 2006). The size of tuberous storage root enlarges depending on the hydroponic culture period and the number of leaves (Eguchi et al., 1996). Therefore, the basic knowledge on osmoregulation defense mechanisms in water deficit tolerance, cv. 'Japanese Yellow' (Yooyongwech et al., 2013) hydroponically grown under 5\% PEG-induced water deficit in a long term period from planting to harvesting is still limited. The aim of this study was to establish the responses of sweetpotato cv. 'Japanese Yellow' to PEG-induced water deficit in term of storage root yield traits, physiological, biochemical and morphological characteristics.

\section{Materials and Methods}

\section{Plant materials and PEG-induced water deficit condition}

Japanese Yellow' cultivar of sweetpotato obtained from Agricultural Extension Group, Phichit province, Thailand, was used as a master stock material. Single vine $(10 \pm 1 \mathrm{~cm}$ in length) cutting without leaf blades was propagated and planted into plastic bags of $15 \mathrm{~cm}$ of diameter and $20 \mathrm{~cm}$ of length,

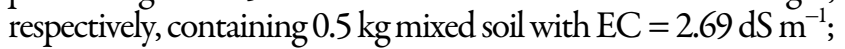

$\mathrm{pH}=5.5$; organic matter $=10.36 \%$; total nitrogen $=0.17 \%$; total phosphorus $=0.07 \%$, and total potassium $=1.19 \%$. The vine cuttings planted in the plastic bag were incubated in a greenhouse at $500-1,000 \mu \mathrm{mol} \mathrm{m}{ }^{-2} \mathrm{~s}^{-1}$ photosynthetic photon flux density (PPFD), $10 \mathrm{~h} \mathrm{~d}^{-1}$ photoperiod, $28 \pm 2{ }^{\circ} \mathrm{C}$ temperature, and $80 \pm 5 \%$ relative humidity. One-week-old vine cuttings were washed to remove the soil particles with tap water and divided in to two groups: (1) positive check to be grown in the plastic pot of $20 \mathrm{~cm}$ of diameter and $25 \mathrm{~cm}$ of length, containing $2 \mathrm{~kg}$ mixed soil, (2) modified nutrient solution (Ingestad and Lund, 1986; Göransson, 1998) with hydroton clay pellets as supporting material. The nutrient solution was prepared and replaced at two days-interval using ebb and flow technique (15 min incubation) for 2 weeks. Then, the $0 \%$ polyethylene glycol (PEG) (control) and 5\% PEG-induced water deficit stress $(\Psi=-0.54 \mathrm{MPa})$ in the nutrient solution were adjusted. Plant grown under well watering in soil culture was validated as positive check. Sweetpotato plants in each treatment were incubated in a greenhouse for 4 months. Growth performances, photosynthetic abilities, water potential, soluble sugar, free proline and storage root yield traits in each treatment were measured.

\section{Growth measurement}

Vine length, leaf, shoot, root dry weight, leaf area, root length, number of root; shoot and root fresh weight of sweetpotato were determined. Leaf area per plant was measured by Root/Leaf Area DT-Scan (Delta-Scan Version 2.03, Delta-T Devices, Ltd., UK). Vine, leaves and roots were dried at $80^{\circ} \mathrm{C}$ in a hot-air oven for 2 days, and then incubated in desiccators before the measurement of vine, leaf and root dry weight.

\section{Biochemical assay}

Free proline in the leaf tissues was extracted and analyzed according to the method of Bates et al. (1973). In brief, fifty milligrams of fresh leaf tissues was ground with liquid nitrogen in a mortar. The homogenate powder was mixed with $1 \mathrm{~mL}$ aqueous sulfosalicylic acid $(3 \%, w / v)$ and filtered through filter paper (Whatman \#1, England). The extracted solution was reacted with an equal volume of glacial acetic acid and ninhydrin reagent $(1.25 \mathrm{mg}$ ninhydrin in $30 \mathrm{~mL}$ glacial acetic acid and 20 $\left.\mathrm{mL} 6 \mathrm{M} \mathrm{H}_{3} \mathrm{PO}_{4}\right)$ and incubated at $95^{\circ} \mathrm{C}$ for $1 \mathrm{~h}$. The reaction was terminated by placing the container in an ice bath. The reaction mixture was mixed vigorously with $2 \mathrm{~mL}$ of toluene. After cooling to $25^{\circ} \mathrm{C}$, the chromophore was measured at 520 nm by spectrophotometer (HACH DR/4000; Model 48000, HACH Company, Loveland, Colorado, USA) using L-proline as a calibration standard. Soluble sugar (sucrose, glucose and fructose) in the root, leaf and storage root tissues were assayed following the method of Karkacier et al. (2003). In brief, fiftymilligram of plant sample was ground in a mortar with liquid nitrogen. One $\mathrm{mL}$ of nanopure water was added and centrifuged at $12,000 \mathrm{rpm}$ for $15 \mathrm{~min}$. The supernatant was collected and filtered through a $0.45 \mu \mathrm{m}$ membrane filter (VertiPure ${ }^{\text {тx }}$, Vertical $^{\circledR}$ ). Twenty micro-litters of the filtrate was injected into a Waters HPLC equipped with a MetaCarb 87C column and a guard column. Deionized water was used as the mobile phase at a flow rate of $0.5 \mathrm{~mL} \mathrm{~min}^{-1}$. The online detection was performed using a Waters 410 differential refractrometer detector and the data was analyzed by Empower software. Sucrose, glucose and fructose (Fluka, USA) were used as the standards. 
166

\section{Physiological analysis}

Osmotic potential in the roots, leaves and storage roots of sweetpotato was measured, according to Lanfermeijer et al. (1991). Chlorophyll $a\left(\mathrm{Chl}_{\mathrm{a}}\right)$, chlorophyll $b$ (Chl $)$, total chlorophyll (TC) and total carotenoids contents in the leaf tissues were assayed according to the method of Shabala $e t$ al. (1998), as well as total carotenoids $\left(\mathrm{C}_{\mathrm{x}+\mathrm{c}}\right)$ content was assayed following Lichtenthaler (1987) method. One hundred milligrams leaf tissue was homogenized in glass vials using $10 \mathrm{~mL}$ of $99.5 \%$ acetone, and blended using a homogenizer. The glass vials were sealed with Parafilm ${ }^{\circ}$ to prevent evaporation, and then stored at $4^{\circ} \mathrm{C}$ for $48 \mathrm{~h}$. $\mathrm{Chl}_{\mathrm{a}}$ and $\mathrm{Chl}_{\mathrm{b}}$ concentrations were measured at $662 \mathrm{~nm}$ and $644 \mathrm{~nm}$ whereas $C_{x+c}$ concentration measured at $470 \mathrm{~nm}$ using UV-VIS spectrophotometer (HACH DR/4000; Model 48000, HACH Company, Loveland, Colorado, USA) against acetone (95.5\%) as a blank. Chlorophyll fluorescence emission was measured from the adaxial surface on the leaf using a fluorescence monitoring system (model FMS 2; Hansatech Instruments Ltd., Norfolk, UK) in the pulse amplitude modulation mode (Loggini et al., 1999; Maxwell and Johnson, 2000). Net photosynthetic ( $P_{n} ; \mu \mathrm{mol} \mathrm{m}$ $\left.{ }^{2} \mathrm{~s}^{-1}\right)$ and transpiration rate $\left(\mathrm{E} ; \mathrm{mmol} \mathrm{m}^{-2} \mathrm{~s}^{-1}\right)$ were measured using a Portable Photosynthesis System with an Infra-red Gas Analyzer (Model LI 6400, LI-COR Inc., Lincoln, Nebraska, USA). Both parameters were measured continuously by monitoring the content of the air entering and existing in the IRGA headspace chamber, according to Cha-um et al. (2007).

\section{Experiment design and statistical analysis}

The experiment was arranged as Completely Randomized Design (CRD) with eight replicates $(n=8)$. The mean values obtained from three treatments were compared using Tukey's HSD and analyzed with SPSS software. In addition, the $t$-test mean comparison in two treatments with PEG or without PEG was validated for 1,2 and 3 months after cultivation.

\section{Results}

\section{Storage root traits and morphological characteristics}

Storage root, vine and root morphological characters of sweet potato plants cv. 'Japanese Yellow' grown under 0\% PEG, 5\% PEG and soil culture for 4 months were demonstrated (Fig. 1). The 5\% PEG treatment induced water deficit stress, leaf chlorosis and toxicity symptoms in plants. Green leaf area and leaf dry weight in plants grown under hydroponic culture were better than those in the soil culture depending on the full nutrient support. In PEG-induced water deficit, leaf dry weight and green leaf area significantly declined by $85.59 \%$ and $95.25 \%$, respectively (Fig. 2A and 2B). Number of storage roots per plant and storage root fresh weight in plants grown under hydroponic culture were lower than those grown in soil culture. Moreover, number of storage roots per plant and storage root fresh weight in plants grown under 5\% PEGinduced water deficit condition dropped by $20 \%$ and $47.38 \%$, respectively (Fig. 2C and 2D). Vine length, number of roots, shoot fresh weight, root fresh weight and root dry weight in plants grown under hydroponic culture were higher than those grown in soil culture, while root length was shorter (Table 1). Under water deficit stress, vine length, root length, number of roots, shoot fresh weight, shoot dry weight and root fresh weight were significantly decreased by $52.02 \%, 22.33 \%$, $28.57 \%, 67.12 \%, 47.99 \%$ and $51.81 \%$ of control (without PEG), respectively (Table 1).

\section{Osmotic potential and osmotic solutes in the cellular levels}

Osmotic potential in the leaf tissues significantly declined by $44.83 \%, 17.43 \%, 31.63 \%$ and $36.95 \%$ of control when plants were exposed to $5 \%$ PEG-induced water deficit for 1, 2, 3 and 4 months, respectively (Fig. 3A). Free proline levels in the leaf tissues of PEG-induced water stress for 2, 3 and 4 months continuously increased for $2.40,2.54$ and 4.14 folds over

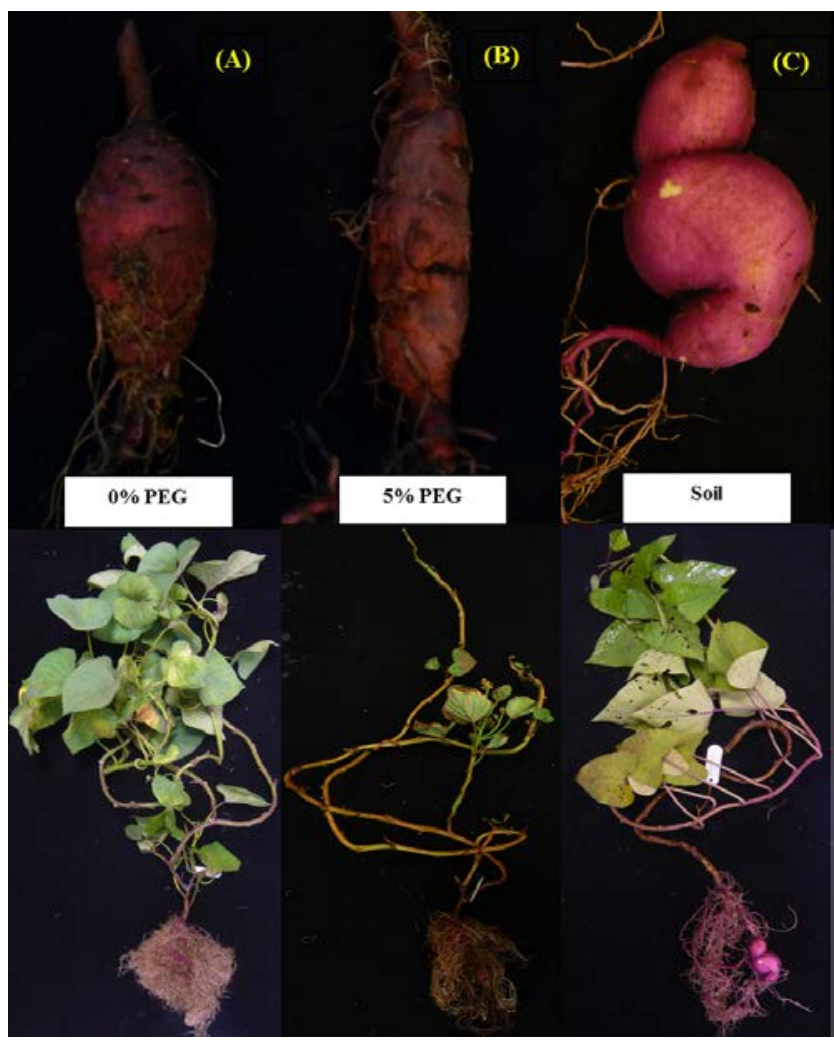

Fig. 1. Storage roots and morphological characteristics of sweetpotato cv. 'Japanese Yellow' grown under hydroponic culture (A) 0, (B) 5\% PEG and in the soil (C) for 4 months

Table 1. Vine length (VL), root length (RL), number of roots (NR), shoot fresh (SFW), shoot dry weight (SDW), root fresh (RFW) and root dry weight $(\mathrm{RDW})$ of sweetpotato cv. 'Japanese Yellow' grown under 0 (control) and 5\% PEG-induced water deficit in the hydroponic culture and, in the soil (positive check) for 4 months

\begin{tabular}{|c|c|c|c|c|c|c|c|}
\hline Treatment & $\begin{array}{c}\mathrm{VL} \\
(\mathrm{cm}) \\
\end{array}$ & $\begin{array}{c}\mathrm{RL} \\
(\mathrm{cm})\end{array}$ & NR & $\begin{array}{c}\text { SFW } \\
(\mathrm{g})\end{array}$ & $\begin{array}{c}\text { SDW } \\
(\mathrm{g})\end{array}$ & $\begin{array}{c}\text { RFW } \\
(\mathrm{g})\end{array}$ & $\begin{array}{c}\text { RDW } \\
(\mathrm{g})\end{array}$ \\
\hline $0 \%$ PEG & $269.67 a$ & $33.90 \mathrm{~b}$ & $14.0 \mathrm{a}$ & $121.52 \mathrm{a}$ & $13.44 \mathrm{a}$ & $54.01 \mathrm{a}$ & $6.75 a$ \\
\hline $5 \%$ PEG & $129.40 \mathrm{~b}$ & $26.33 c$ & $10.0 \mathrm{~b}$ & $39.96 b$ & $6.99 \mathrm{~b}$ & $25.99 \mathrm{~b}$ & $5.91 \mathrm{a}$ \\
\hline Soil & $74.00 \mathrm{c}$ & $65.33 \mathrm{a}$ & $5.33 c$ & $25.02 b$ & $5.41 b$ & $7.93 c$ & $2.33 b$ \\
\hline$A N O V A$ & ** & ** & ** & ** & ** & ** & * \\
\hline
\end{tabular}

Different letters in each column show significant difference at $p \leq 0.01\left(^{* *}\right)$ and $p \leq 0.05\left(^{*}\right)$ by Tukey's HSD 

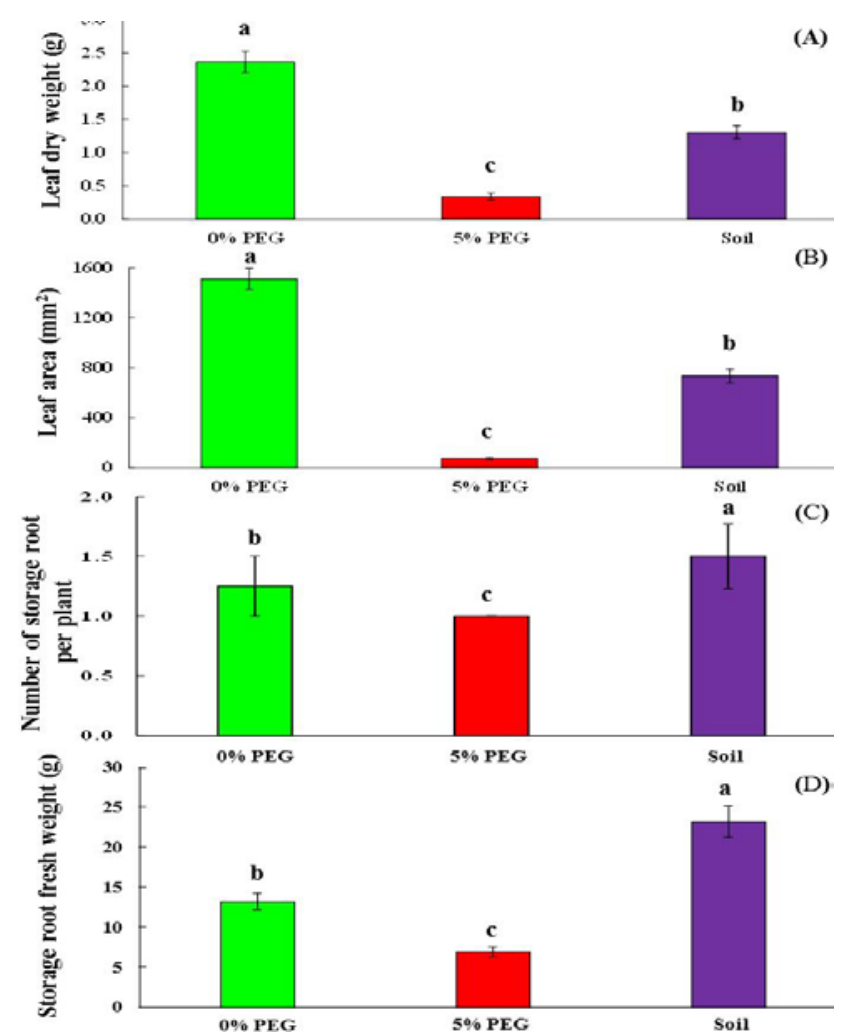

Fig. 2. Leaf dry weight (A), leaf area (B), number of storage roots per plant $(\mathrm{C})$ and storage root fresh weight (D) of sweetpotato cv. 'Japanese Yellow' grown under 0 or 5\% PEG in the hydroponic culture and in the soil for 4 months. Error bars represent $\pm S E$. Different letters in each bar show significant difference at $\mathrm{p} \leq 0.01$ by Tukey's HSD

control, respectively (Fig. 4A). Sucrose content in the leaf tissues was enriched by 2.18, 3.28 and 3.58 folds, when plants were exposed to 5\% PEG-induced water stress for 2, 3 and 4 months, respectively (Fig. 4B). In contrast, osmotic potential in the adventitious fibrous root and tuberous root of sweetpotato was unchanged in either with or without PEG for 1, 2, 3 and 4 months as well as in the soil culture for 4 months (Fig 3B and $3 \mathrm{C}$ ). Total soluble sugar in root tissues were stimulated by 1.69 , 1.91 and 2.43 folds when plants were subjected to 5\% PEGinduced water stress for 2, 3 and 4 months, respectively (Fig. $4 \mathrm{C}$ ). Moreover, total soluble sugar in storage root tissues was moved up to $1.40,1.37$ and 2.11 folds (Fig. 4D).

\section{Photosynthetic abilities and sugar primary products}

Chlorophyll $a\left(\mathrm{Chl}_{\mathrm{a}}\right)$, chlorophyll $b\left(\mathrm{Chl}_{\mathrm{b}}\right)$ and total chlorophyll (TC) in both PEG-induced water deficit and soil culture were lower than those in hydroponic culture without PEG. In water deficit condition, $\mathrm{Chl}_{\mathrm{a}}, \mathrm{Ch}_{\mathrm{b}}$ and $\mathrm{TC}$ levels decreased by $39.21 \%, 48.77 \%$ and $43.07 \%$ of control (Table 2 ). Maximum quantum yield of PSII $\left(\mathrm{F}_{\mathrm{v}} / \mathrm{F}_{\mathrm{m}}\right)$ and photon yield of PSII (ФPSI) in both without PEG and soil culture of sweetpotato were unchanged in each growth stages. In contrast, $\mathrm{F}_{\mathrm{v}} / \mathrm{F}_{\mathrm{m}}$ was significantly decreased for $18.56 \%, 21.88 \%$ and $36.55 \%$ when plants were exposed to $5 \%$ PEG-induced water deficit for 2, 3 and 4 months, respectively (Fig. 5A). Correspondingly, ФPSI decreased by $15.87 \%$ and $38.97 \%$ when subjected to 5\% PEG-induced water deficit for 3 and 4 months, respectively (Fig. 5B). Stomatal conductance ( $\left.g_{s}\right)$ and

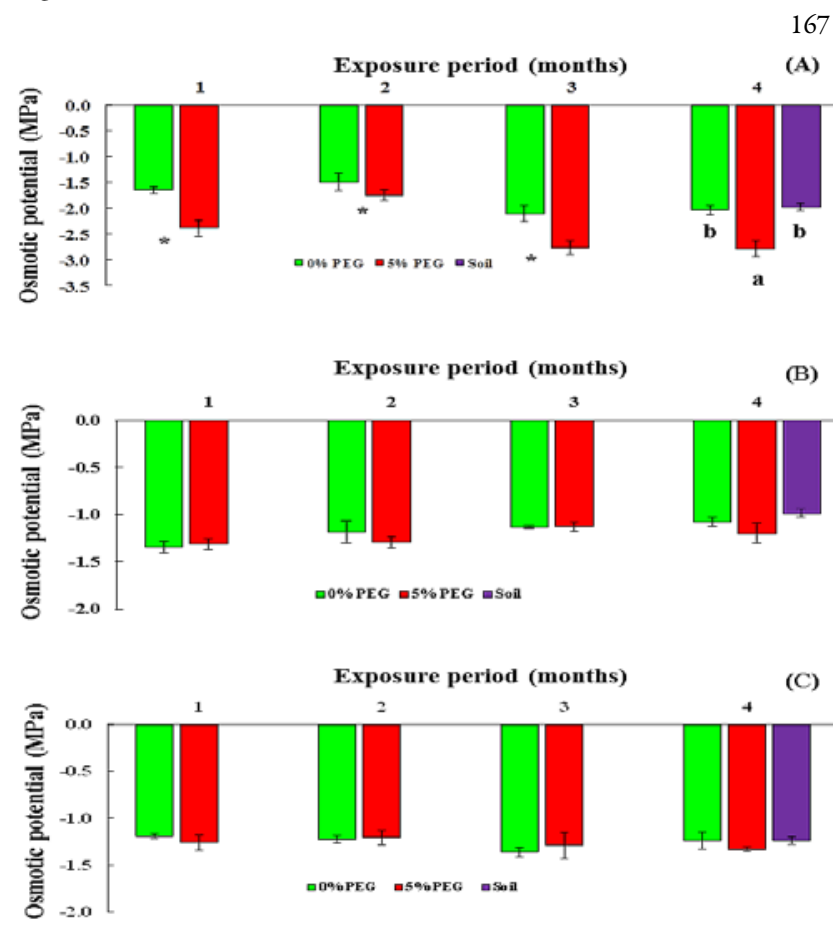

Fig. 3. Osmotic potential $(\mathrm{MPa})$ in leaves $(\mathrm{A})$, root $(\mathrm{B})$ and storage root $(\mathrm{C})$ of sweetpotato cv. 'Japanese Yellow' grown under 0 or $5 \%$ PEG in the hydroponic culture and in the soil for 4 months. Error bars represent \pm SE. Different letters in each bar show significant difference at $\mathrm{p} \leq 0.01$ by Tukey's HSD. *Represents significant difference at $\mathrm{p} \leq 0.01$ by $t$-test
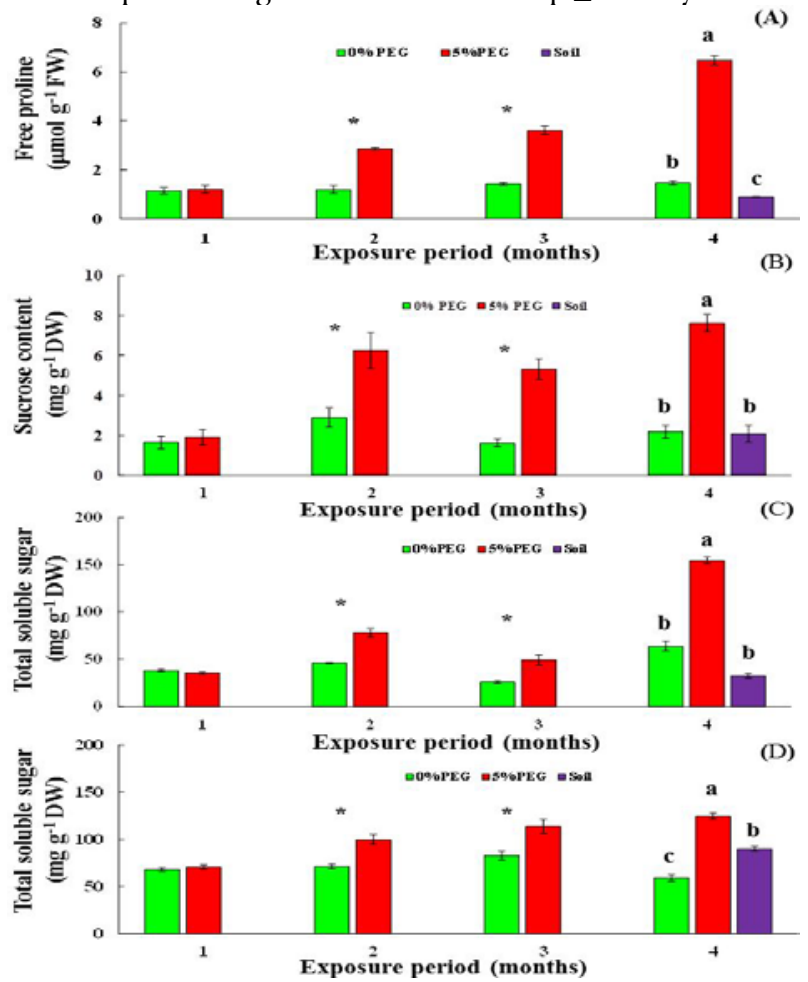

Fig. 4. Free proline (A), sucrose in the leaves (B), total soluble sugar in root (C) and storage root (D) of sweetpotato cv. 'Japanese Yellow' grown under 0 or 5\% PEG in the hydroponic culture and in the soil for 4 months. Error bars represent \pm SE. Different letters in each bar show significant difference at $\mathrm{p} \leq$ 0.01 by Tukey's HSD. ${ }^{*}$ Represents significant difference at $\mathrm{p} \leq$ 0.01 by $t$-test 

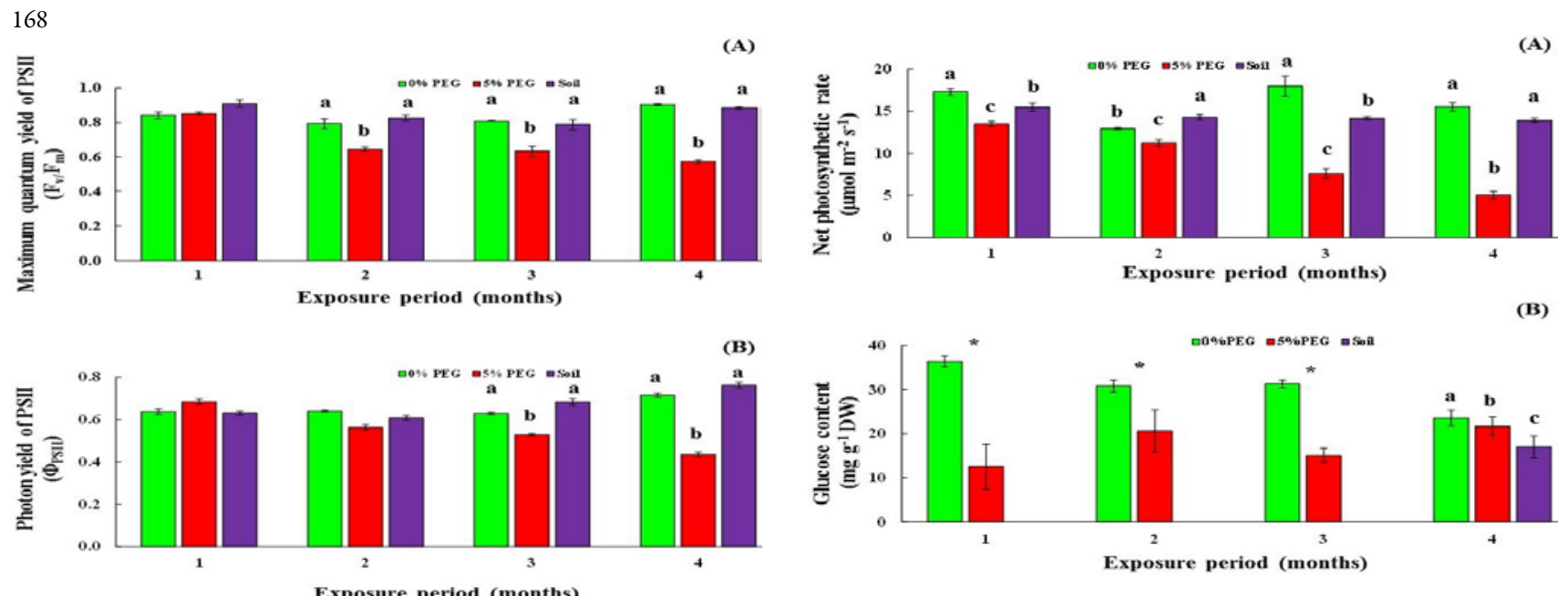

Fig. 5. Maximum quantum yield of PSII $\left(\mathrm{F}_{\mathrm{v}} / \mathrm{F}_{\mathrm{m}}\right)(\mathrm{A})$ and photon yield of PSII ( $\Phi_{\text {PSII }}$ ) in the leaves of sweetpotato cv. 'Japanese Yellow' grown under 0 or $5 \%$ PEG in the hydroponic culture and in the soil for 4 months. Error bars represent \pm SE. Different letters in each bar show significant difference at $\mathrm{p} \leq$ 0.01 by Tukey's HSD

transpiration rate (E) in water deficit stressed plants significantly dropped for $68.90 \%$ and $60.16 \%$ over control, respectively (Table 2 ). Subsequently, net photosynthetic rate $\left(\mathrm{P}_{\mathrm{n}}\right)$ in plants grown under PEG-induced water deficit declined by $21.96 \%, 13.15 \%, 57.78 \%$ and $67.42 \%$, when cultured for 1 , 2, 3 and 4 months, respectively (Fig. 6A). Glucose and fructose, a primary product derived from photosynthesis in the leaf tissues significantly decreased when exposed to PEG-induced water deficit (Fig. 6B and 6C). Glucose in the plants grown under PEG-induced water deficit dropped by $65.72 \%, 33.13 \%$, $51.81 \%$ and $8.11 \%$ when cultured for $1,2,3$ and 4 months, respectively. Similarly, fructose content declined by $22.68 \%$, 13.77\%, 34.61\% and 9.94\% (Fig. 6C). In contrast, sucrose, glucose and fructose levels in roots of water deficit stressed plant were enriched by 1.94, 2.63 and 3.35 folds over control, respectively (Table 3$)$. In tuberous root, sucrose (114.69 $\mathrm{mg} \mathrm{g}^{-1}$ DW) dominated as major soluble sugar, especially in PEGinduced water deficit condition. Sucrose, glucose and fructose

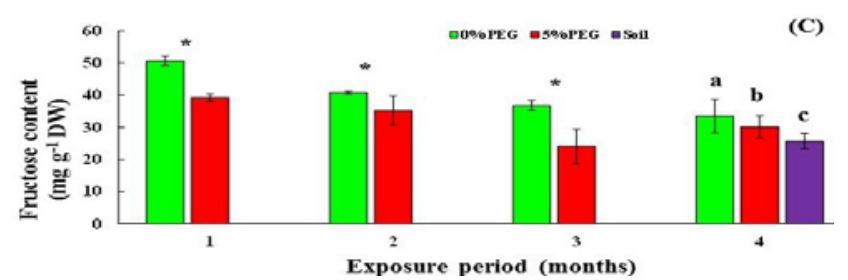

Fig. 6. Net photosynthetic rate (A), glucose (B) and fructose content (C) in leaves of sweetpotato cv. 'Japanese Yellow' grown under 0 or $5 \%$ PEG in the hydroponic culture and in the soil for 4 months. Error bars represent \pm SE. Different letters in each bar show significant difference at $\mathrm{p} \leq 0.01$ by Tukey's HSD. *Represents significant difference at $\mathrm{p} \leq 0.01$ by $t$-test

levels in tuberous roots enhanced by $2.19,1.84$ and 1.40 folds over control, respectively (Table 3).

\section{Discussion}

Overall growth performances of sweetpotato grown under 5\% PEG-induced water deficit were significantly dropped (Table 1), leading to reduced storage root yields when compared to controls (without PEG and in the soil culture; Fig. 2). In sweetpotato, storage root per plant and number of

Table 2. Chlorophyll $a\left(\mathrm{Chl}_{\mathrm{a}}\right)$, chlorophyll $b\left(\mathrm{Chl}_{\mathrm{b}}\right)$, total chlorophyll (TC), stomatal conductance $\left(\mathrm{g}_{\mathrm{s}}\right)$ and transpiration rate (E) in the leaves of sweetpotato cv. 'Japanese Yellow' grown under 0 (control) or 5\% PEG-induced water deficit in the hydroponic culture and in the soil (positive check) for 4 months

\begin{tabular}{|c|c|c|c|c|c|}
\hline Treatment & $\begin{array}{c}\mathrm{Chl}_{\mathrm{a}} \\
\left(\mu \mathrm{g} \mathrm{g}^{-1} \mathrm{FW}\right) \\
\end{array}$ & $\begin{array}{c}\mathrm{Chl}_{\mathrm{b}} \\
\left(\mu \mathrm{g} \mathrm{g}^{-1} \mathrm{FW}\right) \\
\end{array}$ & $\begin{array}{c}\mathrm{TC} \\
\left(\mu \mathrm{g} \mathrm{g}^{-1} \mathrm{FW}\right) \\
\end{array}$ & $\begin{array}{c}\mathrm{g}_{\mathrm{s}} \\
\left(\mathrm{mmol} \mathrm{m}^{-2} \mathrm{~s}^{-1}\right) \\
\end{array}$ & $\begin{array}{c}\mathrm{E} \\
\left(\mathrm{mmol} \mathrm{H}_{2} \mathrm{O} \mathrm{mol}^{-1}\right)\end{array}$ \\
\hline $0 \%$ PEG & $161.2 \mathrm{a}$ & $109.5 \mathrm{a}$ & $270.7 \mathrm{a}$ & $0.164 a$ & $2.46 \mathrm{a}$ \\
\hline 5\% PEG & $98.0 \mathrm{~b}$ & $56.1 b$ & $154.1 b$ & $0.051 \mathrm{c}$ & $0.98 \mathrm{c}$ \\
\hline Soil & $95.0 \mathrm{~b}$ & $57.7 b$ & $152.7 \mathrm{~b}$ & $0.095 b$ & $1.74 \mathrm{~b}$ \\
\hline ANOVA & ** & $* *$ & $* *$ & ** & ** \\
\hline
\end{tabular}

Different letters in each column show significant difference at $p \leq 0.01\left({ }^{* *}\right)$ by Tukey's HSD.

Table 3. Sucrose, glucose and fructose contents in root and storage root tissues of sweetpotato cv. 'Japanese Yellow' grown under 0 (control) or 5\% PEG-induced water deficit in the hydroponic culture and in the soil (positive check) for 4 months

\begin{tabular}{|c|c|c|c|c|c|c|}
\hline \multirow[b]{2}{*}{ Treatment } & \multicolumn{3}{|c|}{ Root } & \multicolumn{3}{|c|}{ Storage roots } \\
\hline & $\begin{array}{c}\text { Suc } \\
\left(\mathrm{mg} \mathrm{g}^{-1} \mathrm{DW}\right)\end{array}$ & $\begin{array}{c}\text { Glu } \\
\left(\mathrm{mg} \mathrm{g}^{-1} \mathrm{DW}\right)\end{array}$ & $\begin{array}{c}\text { Fruc } \\
\left(\mathrm{mg} \mathrm{g}^{-1} \mathrm{DW}\right)\end{array}$ & $\begin{array}{c}\text { Suc } \\
\left(\mathrm{mg} \mathrm{g}^{-1} \mathrm{DW}\right)\end{array}$ & $\begin{array}{c}\text { Glu } \\
\left(\mathrm{mg} \mathrm{g}^{-1} \mathrm{DW}\right)\end{array}$ & $\begin{array}{c}\text { Fruc } \\
\left(\mathrm{mg} \mathrm{g}^{-1} \mathrm{DW}\right)\end{array}$ \\
\hline $0 \%$ PEG & $33.39 \mathrm{~b}$ & $16.47 b$ & $13.87 \mathrm{~b}$ & $52.47 \mathrm{c}$ & $1.28 \mathrm{c}$ & $5.33 c$ \\
\hline $5 \%$ PEG & $64.81 \mathrm{a}$ & $43.34 \mathrm{a}$ & $46.47 \mathrm{a}$ & $114.69 \mathrm{a}$ & $2.35 b$ & $7.48 b$ \\
\hline Soil & $22.09 c$ & $3.47 \mathrm{c}$ & $6.76 c$ & $70.33 b$ & $5.38 \mathrm{a}$ & $14.22 \mathrm{a}$ \\
\hline ANOVA & $* *$ & $* *$ & $* *$ & $* *$ & $* *$ & $* *$ \\
\hline
\end{tabular}

Different letters in each column show significant difference at $p \leq 0.01\left(^{* *}\right)$ by Tukey's HSD 
storage root on $33 \%$ full irrigation significantly decreased by $59.61 \%$ and $29.63 \%$ when compared with $100 \%$ irrigation. The yield traits, storage root per plant $(77.02 \%)$ and number of storage root $(44.44 \%)$ were very sensitive to water shortage, especially in rain fed conditions (Önder et al., 2015). In agreement, leaf fresh, leaf dry, root fresh and root dry weight of Sesuvium portulacstrum grown under water deficit for 12 days were significantly dropped (Slama et al., 2007). In soybean, shoot height was declined by $17.84 \%$ when plants were subjected to $8 \%$ PEG for 14 days, leading to reduce yield traits, number of pods per plant (39.72\% of control), pod dry weight ( $51.85 \%$ of control) and seed yield per plant $(54.25 \%$ of control) (Hamayun et al., 2010). Growth characters such as shoot and root fresh weight, shoot and root dry weight of sunflower cv. 'Musala' under -0.8 MPa PEG-mediated drought stress decreased more than $50 \%$ of control without PEG (Baloğlu et al., 2012). Arial biomass, root length and root biomass of Populus simonii grown under 5\% PEG induced drought stress for 28 days deteriorated by $26.76 \%, 42.37 \%$ and $38.10 \%$, respectively (Meng et al., 2016). In sorghum, plant height, leaf blade biomass and root biomass dropped by $37.63 \%, 55.56 \%$ and $40 \%$ when plants subjected to $20 \%$ PEG for 28 days (O'Donnell et al., 2013). Leaf area is a good indicator to identify the toxicity of PEG-induced drought stress, in Eucalyptus camaldulensis (Utkhao and Yingjajaval, 2015), pistachio (Khoyerdi et al., 2016), Ipomoea pes-caprae (Sucre and Suárez, 2011) and sorghum (O’Donnell et al., 2013).

Leaf osmotic potential of sweetpotato declined relating to 5\% PEG-incubated period (Fig. 3). In potato, leaf water potential of plants grown under 10\% PEG-induced water stress decreased by $-1.1,-1.4$, and $-1.6 \mathrm{MPa}$ when plants were exposed to stress for 1, 2 and 7 days, respectively (Büssis et al., 1998), leading to free proline, glucose and fructose enrichments for osmotic adjustment (Büssis and Heineke, 1998). Free proline and sucrose in cell suspension culture of sweetpotato under $0.6 \mathrm{M}$ mannitol-induced osmotic stress, improved by 5.25 and 3.5 folds over control, respectively, to maintain the cell osmolarity (Wang et al., 1999). In addition, free proline in chickpea cvs. 'ICC4958' and 'Vijay' grown under -1.2 MPa PEG-induced osmotic stress increased by 1.37 and 1.34 folds, relating to stimulate P5CS ( $\Delta^{1}$-pyrroline-5-carboxylate synthetase, a rate-limiting enzyme for proline biosynthesis) activity for $133.7 \%$ and $122.1 \%$ over control, respectively (Pawar et al., 2015). Likewise, free proline osmolyte in sorghum seedlings cvs. 'RSLG-262' and 'RSV-1366' grown under -0.5 MPa PEG-induced water stress was increased by 5.21 and 7.59 folds over control, for P5CS activity for $158 \%$ and $187 \%$, respectively (Damame et al., 2014). In sugar beet, sucrose and free proline in the leaf blade and storage root increased to control the water relation when subjected to $-0.5 \mathrm{MPa}$ sorbitol-induced osmotic stress for $7 \mathrm{~d}$ (Wu et al., 2016). Sucrose and free proline in the leaf blade of plants under PEGinduced water stress generally increased relating the incubation period (Fig. 4). Similarly, free proline and soluble sugar levels in PEG-induced water stress on potato (Büssis and Heineke, 1998), pistachio (Khoyerdi et al., 2016), cassava (Fu et al., 2016), Sesuvium portulacastrum (Slama et al., 2007), Baubinia variegata (Sinhababu and Kar, 2003), lentil (Muscolo et al., 2014) and Apocynum venetum L. (Zhao and Dai, 2015) were increased as major osmotic adjustment.
Chlorophyll photosynthetic pigment degradation and green leaf area reduction were evidently found in plants grown under PEG-induced water stress (Table 2), leading to diminish the $F_{v} / F_{m}$ and ФPSII (Fig. 5) as well as inhibit the $g_{s}$ and $E$ (Table 2) consequently resulting in $P_{n}$ reduction and low levels of glucose and fructose in the leaf tissues (Fig. 6). In the leaf organ, the ADP-glucose pyrophosphorylase (AGPase) gene expression was dominated for transitory starch biosynthesis (source) in the day time and then translocated to the storage root organ (sink) in the night time, relating to the storage root enlargement in the night period (Eguchi et al., 1998; Li and Zhang, 2003). Moreover, sucrose is a major sugar in the leaves, especially in water deficit stress, relating to absent invertase (INV) gene expression subsequently to low glucose and fructose contents ( $\mathrm{Li}$ and Zhang, 2003). $\mathrm{Chl}_{\mathrm{a}}$ and $\mathrm{Chl}_{\mathrm{b}}$ in the leaves of apple seedlings grown under $10 \%$ PEG were significantly degraded, causing to reduction of $P_{n}$ (Kautz et al., 2015). In addition, $\mathrm{Chl}_{\mathrm{a}}$ degradation in Pistacia lentiscus seedlings under $-2.47 \mathrm{MPa}$ PEG-induced water stress was correlated with $\mathrm{F}_{\mathrm{v}} / \mathrm{F}_{\mathrm{m}}(2.41 \%)$ and $\Phi_{\mathrm{PSII}}(8.57 \%)$ reduction as well as $P_{n}$ inhibition $(60.54 \%)$ (Vasques et al., 2016). Sucrose in adventitious fibrous root and storage root under water deficit condition was evidently enriched to control the osmotic potential in the cellular level. Expression of sucrose (sucrose synthase; SuSy 1 and SuSy 2) and starch (AGPase) biosynthesis related-genes in developed storage root was up-regulated while expression level of INV gene (invertase) was very low in storage root initiation stage and absent in medium/mature storage root. This lead to the accumulation of sucrose and starch in the fibrous and tuberous root tissues (Firon et al., 2013; Li and Zhang, 2003).

\section{Conclusions}

In conclusion, osmotic potential in the leaf tissues of sweetpotato plants grown under 5\% PEG-induced water stress was maintained by free proline and sucrose enrichment. Chlorophyll pigments, photosynthetic abilities as well as net photosynthetic rate were significantly declined when plants were exposed at 5\% PEG-induced water deficit, leading to growth inhibition and storage root yield reduction. In the adventitious and tuberous roots, total soluble sugar plays a key role as an osmotic adjustment in plants when subjected to water deficit stress in both short and long term responses.

\section{Acknowledgements}

We would like to sincerely thank National Science and Technology Development Agency (NSTDA, Thailand) for facility and partially funding support and Agricultural Extension Group, Phichit province, Thailand for sweetpotato master stock.

\section{References}

Agilis S, Aggrey BN, Masindew WP (2015). In vitro evaluation of orangefleshed sweet potato genotypes for drought tolerance using polyethylene gycol. In Low J, Nyongesa M, Quinn S, Parker M (Eds). Potato and Sweet Potato in Africa: Transforming the Value Chains for Food and Nutrition Security. CABI Oxfordshire, UK. 
170

Andrade MI, Naico A, Ricardo J, Eyzaguirre R, Makunde GS, Ortiz R, Grüneberg WJ (2016). Genotype $\times$ environment interaction and selection for drought adaptation in sweet potato (Ipomoea batatas [L.] Lam.) in Mozambique. Euphytica 209:261-280.

Baloğlu MC, Kavas M, Aydin G, Öktem HA, Yücel AM (2012). Antioxidative and physiological responses of two sunflower (Helianthus annuus) cultivars under PEG-mediated drought stress. Turkish Journal ofBotany 36:707-714.

Bates LS, Waldren RP, Teare ID (1973). Rapid determination of free proline for water-stress studies. Plant and Soil 39:205-207.

Burri BJ (2011). Evaluating sweet potato as an intervention food to prevent vitamin A deficiency. Comprehensive Reviews in Food Science and Food Safety 10:118-130.

Büssis D, Heineke D (1998). Acclimation of potato plants to polyethylene gycol-induced water deficit II. Contents and subcellular distribution of organic solutes. Journal of Experimental Botany 49:1361-1370.

Büssis D, Kauder F, Heineke D (1998). Acclimation of potato plants to polyethylene gycol-induced water deficit I. Photosynthesis and metabolism. Journal of Experimental Botany 49:1349-1360.

Cha-um S, Supaibulwatana K, Kirdmanee C (2007). Glycinebetaine accumulation, physiological characterizations and growth efficiency in salt-tolerant and salt-sensitive lines of indica rice (Oryza sativa L. ssp. indica) in response to salt stress. Journal of Agronomy and Crop Science 193:157-166.

Damame SV, Naik RM, Dalvi US, Munjal SV (2014). Effect of PEG induced osmotic stress on osmolytes and antioxidative enzymes in sorghum seedlings. Indian Journal of Plant Physiology 19:165-173.

Eguchi T, Kitano M, Eguchi H (1995). Effect of air humidity around tuberous root on sink strength in sweet potato plants grown in a solution-air culture system. Biotronics 24:45-49.

Eguchi T, Kitano M, Eguchi H (1996). New system of hydroponics for growth analysis of sweet potato tuber. Biotronics 25:85-88.

Eguchi T, Kitano M, Eguchi H (1998). Growth of sweet potato tuber as affected by the ambient humidity. Biotronics 27:93-96.

Firon N, la Bonte D, Villordon A, Kfir Y, Lapis E, Perlman TS, Nadir LA (2013). Transcriptional profiling of sweet potato (Ipomoea batatas) roots indicates down-regulation of lignin biosynthesis and up-regulation of starch biosynthesis at early stage of storage root formation. BMC Genomics14:460.

Fitzpatrick TB, Basset GJC, Borel P, Carran F, Penna DD, Fraser PD, Fernie AR (2012). Vitamin deficiencies in human: Can plant science help? ThePlant Cell 24:395-414.

Fu L, Ding Z, Han B, Hu W, Li Y, Zhang J (2016). Physiological investigation and transcriptome analysis of polyethylene gycol (PEG)induced dehydration stress in cassava. International Journal of Molecular Science 17:283.

Gajanayake B, Reddy KR, Shankle MW, Arancibia RA (2013). Early-season soil moisture deficit reduces sweet potato storage root initiation and development. HortScience 48:1457-1462.

Gajanayake B, Reddy KR, Shankle MW, Arancibia RA (2014). Growth, development, and physiological responses of two sweet potato (Ipomoea batatas L. [Lam.]) cultivars to early season soil moisture deficit. Scientia Horticulturae 168:218-228.
Gopal J, Iwama K (2007). In vitro screening of sweet potato against waterstress mediated through sorbitol and polyethylene glycol. Plant Cell Reports 26:693-700.

Göransson A (1998). Steady-state nutrition and growth responses of Betula pendula to different relative supply rates of copper. Plant Cell and Environment 21(8):937-944.

Hamayun M, Khan SA, Shinwari ZK, Khan AL, Ahmad N, Lee IJ (2010). Effect of polyethylene gycol induced drought stress on physio-hormonal attributes of soybean. Pakistan Journal of Botany 42:977-986.

Ingestad T, Lund AB (1986). Theory and techniques for steady state mineral nutrition and growth of plants. Scandinavian Journal of Forest Research 1:439-453.

Islam AFMS, Kubota C, Takagaki M, Kozai T (2006). Effects of ages of plug transplants and planting depths on the growth and yield of sweet potato. Scientia Horticulturae 108:121-126.

Islam MS, Yoshimoto M, Terahara N, Yamakawa O (2002). Anthocyanin compositions in sweet potato (Ipomoea batatas L.) leaves. Bioscience Biotechnology and Biochemistry 66:2483-2486.

Islam S (2006). Sweet potato (Ipomoea batatas L.) leaf: its potential effect on human health and nutrition. Journal of Food Science 71:13-21.

Karkacier M, Ebras M,Uslu MK, Aksu M (2003). Comparison of different extraction and detection methods for sugars using amino-bonded phase HPLC. Journal ofChromatography Science 41:331-333.

Kautz B, Noga G, Hunsche M (2015). PEG and drought cause distinct changes in biochemical, physiological and morphological parameters of apple seedlings. Acta Physiologiae Plantarum 37:162.

Khoyerdi FF, Shamshiri MH, Estaji A (2016). Changes in some physiological and osmotic parameters of several pistachio genotypes under drought stress. Scientia Horticulturae 198:4451.

Kivuva BM, Githiri SM, Yancho GC, Sibiya J (2015). Screening sweet potato genotypes for tolerance to drought stress. Field Crops Research 171:11-22.

Lanfermeijer FC, Koerselman-Kooij JW, Borstlap AC (1991). Osmosensitivity of sucrose uptake by immature pea cotyledons disappears during development. Plant Physiology 95:832-838.

Laurie SM, Calitz FJ, Adebola PO, Lezar A (2013). Characterization and evaluation of South African sweet potato (Ipomoea batatas (L.) Lam) landraces. South African Journal of Botany 85:10-16.

Li XQ, Zhang D (2003). Gene expression activity and pathway selection for sucrose metabolism in developing storage root of sweet potato. Plant and Cell Physiology 44:630-636.

Lichtenthaler HK (1987). Chlorophylls and carotenoids: Pigments of photosynthetic biomembranes. Methods in Enzymology 148:350-380.

Loggini B, Scartazza A, Brugnoli E, Navari-Izzo F (1999). Antioxidant defense system, pigment composition, and photosynthetic efficiency in two wheat cultivars subjected to drought. Plant Physiology 119:10911099.

Maquia I, Muocha I, Naico A, Martins N, Gouveia M, Andrade I, Ribeiro $\mathrm{AI}$ (2013). Molecular, morphological and agronomic characterization of the sweet potato (Ipomoea batatas L.) germplasm collection from Mozambique: Genotype selection for drought prone regions. South African Journal of Botany 88:142-145.

Maxwell K, Johnson GN (2000). Chlorophyll fluorescence-a practical guide. 
Journal of Experimental Botany 51:659-668.

Meng S, Zhang C, Su L, Li Y, Zhao Z (2016). Nitrogen uptake and metabolism of Populus simonii in responses to PEG-induced drought stress. Environmental and Experimental Botany 123:78-87.

Mohanraj R, Sivasankar S (2014). Sweetpotato (Ipomoea batatas [L.] Lam.) A valuable medicinal food: A review.Journal of Medicinal Food 17:733741.

Mortley DG, Bonsi CK, Loretan PA, Hill WA, Morris CE (1994). Relative humidity influences yield, edible biomass, and linear growth rate of sweet potato. HortScience 29:609-610.

Mortley DG, Burrel S, Bonsi CK, Hill WA, Morris CE (2009). Influence of daily light period and irradiance on yield and leaf elemental concentration of hydroponically grown sweet potato. HortScience 44:1491-1493.

Mortley DG, Loretan PA, Bonsi CK, Hill WA, Morris CE (1991). Plant spacing influences yield and linear growth rate of sweet potatoes grown hydroponically. HortScience 26:1274-1275.

Mortley DG, Loretan PA, Hill WA, Bonsi CK, Morris CE (1996). Growth responses of hydroponically grown sweet potato tolerant and intolerant of a continuous daily light period. HortScience 31:209-212.

Motsa NM, Modi AT, Mabhaudhi T (2015). Sweet potato (Ipomoea batatas L.) as a drought tolerant and food security crop. South African Journal ofScience 111:20140252.

Mukhopadhyay SK, Chattopadhyay A, Chakraborty I, Bhattacharya I (2011). Crops that feed the world 5. Sweetpotato. Sweetpotatoes for income and food security. Food Security 3:283-305.

Muscolo A, Sidari M, Anastasi U, Sanronoceto C, Maggio A (2014). Effect of PEG-induced drought stress on seed germination of four lentil genotypes. Journal of Plant Interactions 9:354363.

Nedunchezhiyan M, Byju G, Jata SK (2012). Sweet potato agronomy. Fruit, Vegetable and Cereal Science and Biotechnology 6:1-10.

O'Donnell NH, Møller BL, Neale AD, Hamill JD, Blomstedt CK, Gleadow RM (2013). Effects of PEG-induced osmotic stress on growth and dhurrin levels of forage sorghum. Plant Physiology and Biochemistry 73:83-92.

Önder D, Önder S, Ḉahşkan ME, Ḉahşkan S (2015). Influence of different irrigation methods and irrigation levels on water use efficiency, yield attributes of sweet potatoes. Fresenius Environmental Bulletin 24:33983403.

Pawar VV, Lokhande PK, Dalvi US, Awari VR, Kale AA, Chimote VP, Naik RM (2015). Effect of osmotic stress on osmolyte accumulation and ammonia assimilating enzymes in chickpea. Indian Journal of Plant Physiology 20:276-280.

Placide R, Shimelis H, Laing M, Gahakwa D (2013). Physiological mechanisms and conventional breeding of sweet potato (Ipomoea batatas (L.) Lam.) to drought tolerance. African Journal of Agricultural Research 8:1837-1846.

ShabalaSN, ShabalaSI, Martynenko AI, Babourina O, Newman IA(1998). Salinity effect on bioelectric activity, growth, $\mathrm{Na}^{+}$accumulation and chlorophyll fluorescence of maize leaves: a comparative survey and prospects for screening. Australian Journal of Plant Physiology 25:609616.
Sinhababu A, Kar RK (2003). Comparative responses of three fuel wood yielding plants to PEG-induced water stress at seedling stage. Acta Physiologiae Plantarum 25:403-409.

Slama I, Ghnaya T, Hessini K, Messedi D, Savouré A, Abdelly C (2007). Comparative study of the effects of mannitol and PEG osmotic stress on growth and solute accumulation in Sesuvium portulacastrum. Environmental and Experimental Botany 61:10-17.

Sucre B, Suárez N (2011). Effect of salinity and PEG-induced water stress on water status, gas exchange, solute accumulation, and leaf growth in Ipomoea pes-caprae. Environmental and Experimental Botany 70:192203.

Tekalign T (2007). Genotype $\times$ environment interaction for root yield of elite sweet potato (Ipomoea batatas [L.] Lam.) genotypes. South African Journal of Plant and Soil 24:144-146.

Truong VD, Deighton N, Thompson RT, McFeeter RF, Deam LO, Pecota KV, Yencho GC (2010). Characterization of anthocyanins and anthocyanidins in purple-fleshed sweet potato by HPLC-DAD/ESIMS/MS. Journal of Agricultural Food Chemistry 58:404410.

Utkhao W, Yingiajaval S (2015). Changes in leaf gas exchange and biomass of Eucalyptus camaldulensis in response to increasing drought stress induced by polyethyleneglycol. Trees 29:1581-1592.

Vasques AR, Pinto C, Dias MC, Correia CM, Moutinho-Pereira JM, Vallejo, Keizer JJ (2016). Physiological response to drought in seedlings of Pistacialentiscus (mastic tree). New Forests 47:119-130.

Villordon A, la Bonte D, Solis J, Firon N (2012). Characterization of lateral root development at the onset of storage root initiation in 'Beauregard' sweet potato adventitious roots. HortScience 47:961-968.

Wang M, Xiong Y, Zeng M, Li H, Zhang T, Liang Y (2010). GC-MS combined with chemometrics for analysis of the components of the essential oils of sweet potato leaves. Chematographia 71:891-897.

WangHL, Lee PD, Liu LF, Su JC (1999). Effect of sorbitol induced osmotic stress on the changes of carbohydrate and free amino acid pool in sweet potato cell suspension cultures. Botanical Bulletin of Academia Sinica 40:219-225.

Wu GQ, Feng RJ, Shui QZ (2016). Effect of osmotic stress on growth and osmolytes accumulation in sugar beet (Beta vulgaris L.) plants. Plant, Soil andEnvironment 62:189-194.

Yooyongwech S, Theerawitaya C, Samphumphuang T, Cha-um S (2013). Water-deficit tolerant identification in sweet potato genotypes [Ipomoea batatas (L.) Lam.] in vegetative developmental stage using multivariate physiological indices. Scientia Horticulturae 162:242-251.

Zhao H, Dai H (2015). Physiological response of Apocynum venetum L. seedlings under osmotic stress. Bangladesh Journal of Botany 44:551556. 